\title{
The Influence of the Implementation of Job Rotation on Employees' Perceived Job Satisfaction
}

\author{
Anna Elizabeth Van Wyk ${ }^{1}$, Ilze Swarts ${ }^{1} \&$ Chipo Mukonza ${ }^{1}$ \\ ${ }^{1}$ Tshwane University of Technology, South Africa \\ Correspondence: Chipo Mukonza, Faculty of Management Sciences, Polokwane Campus 109 Market Street, \\ Polokwane, South Africa. E-mail: chiponyam@gmail.com
}

Received: July 18, 2018

doi:10.5539/ijbm.v13n11p89
Accepted: September 12, 2018

Online Published: October 12, 2018

\begin{abstract}
The aim of the study was to determine the influence of the implementation of job rotation on employees' perceived job satisfaction, and to identify the key factors that would influence the adoption of a job rotation strategy by the Registrar's environment of a University of Technology, South Africa. A qualitative research approach was chosen for this study. Primary data was collected through a combined focus and nominal group technique. The Registrar's environment at the University of Technology was used for the research. The Registrar's structure consists of three departments, of which the staff of only two departments were used in the focus groups. Purposive sampling was employed to invite 34 employees from the two departments, across five post levels. Three focus groups consisting of 22 participants (six to ten participants per group) were conducted. Methods used to capture data included digital recording and note taking. The raw data was converted into transcriptions, and analysed and interpreted through the Tesch's mechanics of interpretational qualitative content analysis. From the research conducted it was evident that the general feeling of participants was that the implementation of a job rotation strategy by the Registrar's environment would positively impact job satisfaction, should certain key factors be taken into consideration. A job rotation strategy should be well communicated to all employees and the involvement of all stakeholders, including employees, should be sought when such a strategy is developed.
\end{abstract}

Keywords: job rotation, employee, perceived employee satisfaction

\section{Introduction}

Administrative work, since it is routine work, could easily lead to boredom, and people working in administrative roles are more likely to become bored and dissatisfied in their jobs (Adams, 2011). A range of issues, including repetitious work, causes boredom, and where boredom exists, unproductive attitudes and behaviours such as apathy, disinterest in job(s), unhappiness, frustration, escapism and avoidance, dominate. According to Dhanraj \& Parumasur (2014:683), "A bored employee can have a substantial negative impact on the level of motivation of other employees". Demotivated, and therefore dissatisfied employees, will ultimately result in high absenteeism and employee turnover rates, which will lead to poor customer service, according to Dhanraj and Parumasur (2014:683).

Grossman (2003:52) argues that a job rotation programme offers promising employees customised assignments in an effort to give them a rounded view of the entire operation, that would decrease boredom and enhance their perceived level of job satisfaction. Trivellas and Dargenidou (2009:387) argue that most of the research on job satisfaction has been focused on profitable industrial and service organisations, but that there is a growing interest in employee satisfaction in higher education. Kusku, as quoted by Trivellas and Dargenidou (2009:387) states that employee satisfaction in higher education institutions is a very important factor in achieving university accountability and quality, and that employee satisfaction is positively related to improved quality.

Much of the available literature that examines employees' attitudes toward job rotation, tends to focus on manufacturing environments, and not on administrative or support environments. It is against this background that the following investigative questions arise:

(1) What influence would the implementation of a job rotation strategy have on the perceived job satisfaction of employees in the Registrar's environment of a University of Technology? 
(2) What key factors would influence the adoption or non-adoption of a job rotation strategy by the Registrar's environment of a University of technology?

The next section explores a literature review on job rotation and employees' perceptions on job satisfaction. The third section provides the materials and methods that were used in the study. The fourth section comprises the results and a discussion. The last sections provide policy implication, recommendations and conclusions.

\section{Conceptualisation, Issues and Challenges}

\subsection{Job Rotation}

Brunold and Durst (2012) argue that too often, many organisations suffer from increasing bureaucracy and standardised processes that consequently decrease freedom and flexibility. Increasing administrative efforts lead to numerous hierarchical levels with many specialists. "Additionally, higher competition among employees on numerous hierarchical levels might lead to the abuse of knowledge as an instrument of hierarchical power and ambition" (Brunold \& Durst, 2012). This asset (knowledge) is not revealed to other employees, but rather kept to secure one's position. One of the common tools used to cope with these challenges, is job rotation.

Hsieh and Chao (2004) state that job rotation is adopted to address employees' feelings of monotony, boredom and fatigue as a result of job simplification and specialisation, and to empower workers with the ability to help each another. Boredom, according to Game (2007), is an unpleasant, transient affective state in which the individual feels a pervasive lack of interest in an activity and finds it difficult to concentrate on the current activity. Runcie, as quoted by Game (2007) argues that some individuals respond to boredom by sabotaging the production process, engaging in unsafe work practices or stealing company property. Game (2007) also states that boredom correlates strongly and positively with job satisfaction, and found that it is generally assumed that monotonous or repetitive tasks automatically lead to boredom. Hackman and Oldham, as quoted by Game (2007) suggest that by changing the nature of a job, employees will experience greater interest and job satisfaction and therefore a diverse range of strategies may be adopted to cope with boredom, and that managers should identify low boredom-copers and offer them individualised job redesign solutions (Game, 2007).

"Although job satisfaction does not influence the quantity and quality of performance, it does influence citizenship behaviours, turnover, absenteeism, and preferences and opinions about unions. As a result of these influences, managers continue to search for techniques and programmes that improve employee job satisfaction" (Gibson, Ivancevich, Donnelly \& Konopaske, 2012). Job rotation is one of the techniques that can be used to increase job satisfaction.

According to Origo and Pagani (2008), economists agree that flexibility should produce the relevant effect on workers' job satisfaction. Origo and Pagani (2008) state that all flexible work arrangements can be classified into two main groups, namely quantitative and qualitative flexibility. Job rotation is an example of qualitative flexibility. Grossman (2003) argues that while larger companies are more likely to invest in job rotation programmes, businesses of all sizes might want to consider the implementation of such a programme when they see all the advantages it provides.

Fiester, Collis and Cossack (2008) state that job rotation can increase product quality, create an opportunity for employees to explore alternative career paths, and prevent stagnation and job boredom. According to Miller, Dhaliwal and Magas, as quoted by Huang (1999), the implementation of job rotation could reduce fatigue and boredom in production jobs, which would contribute to continued productivity. Shackleton (1981) argues that job rotation can increase job satisfaction, decrease boredom, reduce absenteeism, reduce labour turnover, and increase the quantity and quality of output. Dhanraj and Parumasur (2014:683) add that job rotation can relieve boredom and monotony.

Economists are primarily interested in job satisfaction as an economic variable as highly satisfied workers are also motivated more and hence more productive, which has a positive effect on overall profitability. They have found that job rotation has a positive impact on employee well-being" (Origo \& Pagani, 2008). Origo and Pagani (2008) further argue that the impact of flexibility on job satisfaction changes according to workers' characteristics, as workers with different skills are likely to be influenced in different ways, by flexibility. Flexibility should not be adopted as a general policy to enhance employee performance, but should target only those workers who are more likely to be positively influenced by it.

\subsection{Job Satisfaction}

Human resource managers in South Africa constantly face concerns about employee productivity and job satisfaction, as South Africa has one of the lowest productivity levels in the world (Dhanraj \& Parumasur, 2014). Spector (1997) states that job satisfaction can be considered as a global feeling about the job or a related 
constellation of attitudes about various aspects or facets of the job. The concepts of job satisfaction and job attitude are frequently used interchangeably. Job satisfaction is a measure of the feeling towards work of a specific person, rather than the feeling towards work of a group of workers. A person with high job satisfaction reveals a positive attitude towards his or her job, while a person who is dissatisfied with his or her job reveals a negative attitude towards his or her job (Werner, 2007).

The attention given to job satisfaction in recent years has become more closely associated with broader organisational approaches to improved job design and the quality of work life, according to Mullins (1996). Choo and Bowley (2007) add that it is important to measure job satisfaction, as organisations with satisfied employees generally have satisfied customers. Guinot, Chiva and Roca-Puig (2014) state that job satisfaction is positively related to trust. High levels of interpersonal trust can be positively associated with job satisfaction. When mutual trust spreads among all people in an organisation, job stress can be reduced and levels of job satisfaction can rise. "Increased trust within organisations improves the ability of workers to cope with stressful life events, and enables them to be more satisfied in their jobs" (Guinot et al., 2014). Therefore, management should foster a climate of trust as a strategy to improve job satisfaction.

Confidence, loyalty and ultimately, improved quality in the output of the employees, are created by satisfaction, according to Tietjen and Myers (1998). Choo and Bowley (2007) argue that job satisfaction is influenced by the work environment, company values and job responsibilities. Guinot et al. (2014) further argue that job satisfaction is highly subjective and varies with time. Job satisfaction includes general elements and specific elements. The whole perception of job satisfaction is considered as a general element, and specific elements are, for example, job security, pay, co-workers, supervision and personal growth and development. Pay, promotion opportunities, co-workers, supervision and the work itself are the most common facets of satisfaction. Teh and Sun (2012) confirm that employees who rate their jobs as important, experience more job satisfaction and are more committed to the organisation. According to Mullins (1996), job satisfaction is a complex concept and is difficult to be measured objectively. A wide range of variables relates to individual, social, cultural, organisational and environmental factors that affect job satisfaction, namely:

- Individual (personality, education, intelligence and abilities, age, marital status, orientation to work).

- Social (relationships with co-workers, group working and norms, opportunities for interaction, informal organisation).

- Organisational (nature and size, formal structure, personnel policies and procedures, employee relations, nature of the work, technology and work organisation, supervision and leadership styles, management systems, working conditions).

- Environmental (economic, social, technical and governmental issues).

Wright (2006) states that job satisfaction is partially based on what a person feels and partially based on what a person thinks. When a job is redesigned, it could lead to new challenges for staff and will improve job satisfaction. According to Garg and Rastogi (2006), it is essential to design jobs in order for stress to be reduced, motivation to be enhanced and the satisfaction of employees, as well as their performance, to be improved. Job design has advantages for the organisation and for employees. Job rotation is a job design approach widely used by many organisations at various levels and in many departments. It is a technique followed by organisations to improve workers' performance and increase their commitment to their work. This acts as a motivating factor and helps with employee development. It decreases monotony in work, prepares employees to cope with management challenges, defines the more productive positions and improves the level of motivation of the employees, according to Mohan and Gomathi (2015).

\subsection{Theoretical Framework}

Theoretical conceptualisations on the determinants of job satisfaction can be divided into a situational approach, a dispositional approach and an interactionist approach. According to the situational approach, job satisfaction reflects certain characteristics of the job (favourable job characteristics should lead to higher job satisfaction). In the dispositional approach, job satisfaction is a function of individual dispositions. Some individuals will experience higher job satisfaction than others, irrespective of working conditions. Situational and dispositional approaches are not mutually exclusive, as they are integrated into the interactionist approach, conceptualising the interplay between situational and dispositional variables. The interactionist approach is better known in literature as the person-job fit approach. This approach concludes that different situational characteristics inspire job satisfaction for different persons," (Swarts, 2008).

The Job Characteristics Model of Hackman and Oldman, according to Swarts (2008:45), is an example of the 
situational approach. According to Fried and Ferris (1987), the five crucial characteristics that have been associated with job satisfaction are pay, the job itself, promotion opportunities, the supervisor and co-workers, according to Gibson et al. (2012), who adds that "job satisfaction depends on the levels of intrinsic and extrinsic outcomes and how the jobholder views those outcomes. Fairbrother and Warn (2002:8) indicate that there are strong connections between dimensions of the workplace, stress and job satisfaction. Guinot et al. (2014) argue that job stressors are predictive of job dissatisfaction.

\subsection{Influences on Job Satisfaction}

Furnham, as quoted by Guinot et al. (2014), categorises the factors that can influence job satisfaction into the following three groups:

- Organisational policies and procedures (remuneration package, supervision, decision-making practices).

- Task or job characteristics (aspects of the total workload, variety of skills applied, autonomy, feedback and the physical nature of the working environment).

- $\quad$ Personal aspects (self-image, ability to deal with stress and general satisfaction with life).

The desired levels of discretion in organisations' work patterns (variety and flexibility) may reflect the need to feel in control and achieve self-satisfaction in task performance (Zeffane, 1994). According to Droussiotis and Austin (2007), the following factors influence job satisfaction:

- Demographic factors (age, gender)

- Psychological and genetic factors (temperament, self-worth, emotional dissonance)

- Company operations (company policies, work-family balance, support for diversity in the workplace, The company's grievance system's support of procedural and distributive justice, The number of control/autonomy employers (autonomy in decision making), Bureaucratic organisations, Meaningful work, A good physical work environment, Friendly co-workers, Work in which employees can excel , Competence of supervisor

A person's feeling of satisfaction at work is influenced by factors that differ from one individual to another, such as personality, the influence of society, the situation in the workplace and values, according to Tomazevic, Seljak and Aristovnik (2014). According to Mullins (1996), some of the factors that have a major influence on job satisfaction are frustration and alienation, the nature of technology, meaningful work and the nature of supervision, work and psychological well-being, and stress at work. Lund (2003) has found that employees in strong organisational cultures tend to express greater job satisfaction.

Many factors influence job satisfaction. A worker can be relatively satisfied with one aspect of the job and dissatisfied with other aspects of the job. A person will experience job satisfaction if he or she is satisfied with most of the factors that are considered relevant (Swarts, 2008). "Job rotation is best known and used for training new entrants to an organisations or bolstering the development of high-potential employees. It can, however, be used for other purposes as well, including fostering innovation, cushioning a company against loss of key employees, and to reinvigorate the workforce," (HR Focus, 2008:6). Job rotation creates the opportunity to design work systems leveraging individual desires for growth and organisational needs for optimising the workforce, as stated by Casad (2012). It offers the opportunity for improved employee satisfaction, increased skills development, and greater understanding of employees' strengths.

Robbins and Judge (2009) argue that job rotation can be used when employees suffer from over-routinisation of their work. Job rotation is defined as the periodic shifting of employees from one task to another. When an activity is no longer challenging, employees are rotated to another job, usually at the same level, that has similar skills requirements. Job rotation is also called cross-training.

The growing concerns with workplace equality and corporate social responsibility have entered the discussion on the need or desire for job rotation. Executives have recognised that rotation can be a means for communicating, and diffusing an organisation's culture (Casad, 2012). According to Casad (2012), the products of the organisational culture can often be attended to through increased cross- functional communication and boundary spanning, which is accomplished through job rotation, addressing social, racial and economic inequalities in the workplace. These perspectives align well with the learning organisation strategy and are consistent with the three primary reasons for implementing job rotation, namely skill development, employee satisfaction, and the identification of strengths. 


\subsection{Reasons for Implementing an Effective Job Rotation Program in an Organisation}

According to Fiester, Collis and Cossack (2008), the reasons for implementing a job rotation system include the following:

- An increase in the potential quality of products (services).

- The possibility of alternative career paths for employees.

- The prevention of stagnation and job boredom.

According to Maddock and Vitn (2009), job rotation could create renewed energy, help employees learn new skills, and result in innovation and new ideas. Burke and Moore (2000) add that when focusing on the structural element, rotation programmes enhance competitive advantage by integrating knowledge and adding flexibility to an organisation's structure. Dhanraj and Parumasur (2014a) confirm that employees who are rotated stay challenged, feel fulfilled and develop a sense of loyalty to their organisation. Khan, Rasli, Yusoff, Tariq, Abid-ur-Rahman and Khan (2014) say that job rotation is a brilliant way for organisations to train employees.

Hsieh and Chao (2004) point out that job rotation is sometimes adopted to address employees' feelings of monotony, boredom and fatigue as a result of job simplification and specialisation, and for workers to obtain the ability to help each another. Another reason is job burnout. Various studies indicate that job burnout has an adverse influence on both individuals and companies, as in feelings of depression and failure, quitting the job, turnover, diminishing organisation commitment, lower productivity and physical sickness, and it affects the quality of employees' work.

"From a Human Resources viewpoint, job rotation is the way to achieve such objectives as staffing jobs, orientating new employees, preventing job boredom, training employees and enhancing their career development. Some of the most common reasons for job rotation are to broaden the individual's experience and improve knowledge and skill," (Jaturanonda, Nanthavanij, \& Chongphaisal, 2006).

\subsection{Reasons Why Employees Would Adapt to a Job Rotation Program}

Employees will take part in a job rotation programme when they want to broaden, deepen or take advantage of their competence, or when they are ageing employees who want to change their jobs, according to Slikaniemi (2009). Career and job rotation possibilities support employees' career development prospects. Job rotation possibilities strengthen both the professional development of individual employees and the competence development of work communities. Dhanraj and Parumasur (2014a) note that job rotation may be used as a solution for employees who feel throttled by a lack of challenge in their work, or by over-routinisation.

Employees who practised job rotation are better able to find alternative work when their employment is terminated, as they have gained many skills in the jobs they rotated to within the organisation" (Dhanraj \& Parumasur, 2014b). "Employees have perceived that job rotation has a positive impact on their productivity and job security, and on the organisation itself. With regard to the perceived impact of job rotation on employees, employees see the personal benefits to them as fulfilling their need for challenge, enhancing self-confidence and making them more marketable" (Dhanraj \& Parumasur, 2014b). These results also reflect that employees believe that job rotation increases their understanding, co-ordination and co-operation, as well as enhancing their ability to cope with changes in the business.

\section{Method}

The study had twin objectives which were firstly, to explore the influence that the implementation of a job rotation strategy would have on the perceived job satisfaction of employees in the Registrar's environment and secondly, to explore the key factors that would influence the adoption or non-adoption of a job rotation strategy by the Registrar's environment at a University of Technology, South Africa.

According to Creswell (2014), a research approach is the plan, design and procedure for research that span the steps from broad assumptions to detailed methods of data collection, analysis and interpretation. A qualitative research approach was followed in this research since data would be collected by using words, instead of numbers, and since open-ended questions would be asked. The purpose of the study was exploratory. New insights, views and contributions from participants were explored to determine if job rotation would have an influence on their perceived job satisfaction. The research study employed qualitative content analysis methodology. According to Patton (2002), any qualitative data reduction and sense-making effort that takes qualitative material and attempt to identify core consistencies and meanings, can be viewed as qualitative 
content analysis.

Purposive sampling was used to conduct this study. Saunders, Lewis and Thornhill (2012) define purposive sampling as a non-probability sampling procedure in which the judgment of the researcher is used to select the cases that make up the sample. This can be done on the basis of extreme cases, homogeneity (similarity), critical cases, theoretical cases or typical cases. Since the object of qualitative research is not generalisability but transferability, sampling should be theoretical and purposive as stated by White and Marsh (2006:36). It was important for the researcher to choose a group of participants that are not too heterogeneous but rather homogeneous, in order for them to feel comfortable to share their views and experiences. Focus groups consisted of participants on the same post level to avoid the generation of power issues and promote the comfort of participants and therefore won't feel threatened by their supervisors or participants on higher post levels. Jayasekara (2012) recommends that focus groups should be homogeneous in terms of status, class, occupation since they could have an influence whether participants interact with each other.

The inclusion criteria for participants in the focus group was that they are employed in an administrative environment (Registrar's environment) where they are engaged in routine work and would likely experience boredom. According to Adams (2011), administrative work, since it is routine work, could easily lead to boredom, and people working in administrative roles are more likely to become bored and dissatisfied in their jobs.

The researchers conducted a combined focus and nominal group technique. This technique was used because participants will first generate ideas in the presence of each other and then write down their ideas individually. Jayasekara (2012) states that it is well established that the focus group method is a useful and effective mechanism in which the researcher is interested in processes whereby a group jointly constructs meaning about a topic. According to Barry, Steyn and Brent (2009), the nominal group technique has been found to produce many ideas relative to a specific problem. The researchers wanted all participants to air their views and ensure that the ideas of one or two of the participants don't dominate. Data collection also included a review of academic literature. Digital recording and note-taking were utilised to capture data. The raw data was converted into transcriptions and analysed and interpreted through Tesch's mechanics of interpretational qualitative content analysis. The aim of the analysis was to find patterns in the transcriptions.

Creswell (2014) asserts that objectivity and truthfulness are critical for research. First and foremost, the researcher seeks believability, based on coherence, insight and instrumental utility and trustworthiness, through a process of verification rather than through traditional validity and reliability measures. Jayasekara (2012:414) states that although the terms reliability and validity are essential criteria for quality in quantitative paradigms, credibility, neutrality, consistency and applicability or transferability are the essential criteria for quality in qualitative paradigms. The examination of trustworthiness is crucial to ensure reliability and validity in qualitative research. The following guidelines for quality focus group research apply:

- A lack of precise and consistent research questions damages the theoretical interval validity of focus groups. Clarity of research questions can both provide relevant answers to the research and ensure that it is repeatable.

All ethical rules and guidelines of the University of Technology were adhered to during the data collection process. The study adhered to the following ethical guidelines:

- Permission to do this study was granted by the Registrar of the University of Technology.

- Participants gave their consent to participate by signing a consent form.

- Focus groups were conducted in an environment suitable to the participants, which did not expose them to any physical or psychological harm.

- All participants were informed beforehand by means of the invitation.

\section{Results and Discussion}

In According to Creswell (2013:180), data analysis in qualitative research consists of preparing and organising the data for analysis, then reducing the data into themes through a process of coding and condensing the codes.

\subsection{Demographic Profile}

It was important to illustrate the demographic profile of the participants before the results were analysed, as this would give the reader an understanding of the sample profile. The following demographic questions were asked: post level, number of years at the University of Technology, age, and campus where currently employed. 


\subsubsection{Distribution of Participants Based on Post Level}

The table and chart below show the sample distribution based on the post level of participants.

Table 1. Post level frequency

\begin{tabular}{lll}
\hline Post Level & Participants & Percentage \\
\hline 5 and 7 & 10 & $45 \%$ \\
8 & 6 & $27.5 \%$ \\
10 & 6 & $27.5 \%$ \\
Total & $\mathbf{2 2}$ & $\mathbf{1 0 0} \%$ \\
\hline
\end{tabular}

Table 1 illustrate that most participants were on post levels 5 and 7 (management). They comprised $45 \%$ of the participants, whereas post levels 8 and 10 (supervisors and administrators) both comprised $27.5 \%$ each of the sample. Of the sample of 22, there were ten participants on Post Levels 5 and 7, six participants on Post Level 8, and six participants on Post Level 10. Management (Post Levels 5 and 7) was the biggest group to attend the focus groups. The reason for this is that management happened to attend a meeting on the Pretoria Campus on the day of the focus groups, and the chairperson gave all of them permission to attend.

4.1.2 Distribution of Participants Based on Years of Experience at the University of Technology

The chart below shows the sample distribution based on the years of experience of participants at the University of Technology.

Table 2. Years of experience at the university of technology

\begin{tabular}{lll}
\hline Years of experience & Participants & Percentage \\
\hline $1-5$ & 1 & 4.5 \\
$6-10$ & 4 & 18.3 \\
$11-15$ & 1 & 4.5 \\
$16-20$ & 4 & 18.3 \\
$21-25$ & 5 & 22.7 \\
$26-30$ & 6 & 27.2 \\
$31-35$ & 1 & 4.5 \\
Total & $\mathbf{2 2}$ & $\mathbf{1 0 0 \%}$ \\
\hline
\end{tabular}

Table 2 indicates that $27.2 \%$ of the participants had between 26 and 30 years of experience at TUT. The group with 21 to 25 years of experience comprised $22.7 \%$ of the participants. The groups with between 6 to 10 years, and 16 to 20 years of experience both comprised $18.3 \%$ of the participants. Lastly, the groups with between 1 to 5,11 to 15 , and 30 to 35 years represented only $4.5 \%$ of the total of 22 participants. Staff members with between 26 and 30 years of experience were the biggest group to attend the focus groups.

\subsubsection{Distribution of Participants Based on Age Group}

The percentages and frequencies of the sample, based on age group, are depicted below.

Table 3. Age frequency

\begin{tabular}{lll}
\hline Age & Number & Percentage \\
\hline $30-35$ & 3 & 13.7 \\
$36-40$ & 2 & 9.1 \\
$41-45$ & 3 & 13.7 \\
$46-50$ & 8 & 36.3 \\
$51-55$ & 4 & 18.2 \\
$56-60$ & 1 & 4.5 \\
$60-65$ & 1 & 4.5 \\
Total & $\mathbf{2 2}$ & $\mathbf{1 0 0 \%}$ \\
\hline
\end{tabular}

Table 3 indicates that $36.3 \%$ of the participants were between the ages of 46 and 50 (eight of the 22 
participants in the sample). The next age group was the group aged between 51 and 55 years, with four participants comprising $18.2 \%$ of the participants. The age groups between 30 and 35, and between 41 and 45 represented $13.7 \%$ of the participants in each of the age group and had three of the 22 participants each. The following age group, participants between the ages of 36 and 40 , represented $9.1 \%$ of the participants (two of the 22 participants). Lastly, the two groups between 56 and 60 years and between 60 and 65 years had the smallest number of participants. Both of these groups represented only $4.5 \%$ of the total of 22 participants. Staff members between the ages of 46 and 50 years were the biggest group to attend the focus groups.

\subsection{Influences of Job Rotation on Perceived Job Satisfaction}

The objective of the study was to explore the influence that the implementation of a job rotation strategy would have on the perceived job satisfaction of employees in the Registrar's environment. Table 4 below provides some of the responses to influences of job rotation on perceived job satisfaction.

Table 4. Influences of job rotation on perceived job satisfaction

\begin{tabular}{|c|c|c|c|c|c|c|}
\hline Post Level & $\begin{array}{l}\text { Most Important } \\
\text { Influence Job Rotation Will Have On } \\
\text { Perceived Job Satisfaction }\end{array}$ & $\begin{array}{l}\text { Number Of } \\
\text { Responses Perceive That } \\
\text { Job Rotation Will } \\
\text { Increase Job Satisfaction }\end{array}$ & $\begin{array}{l}\text { Number Of } \\
\text { Responses } \\
\text { Rotation } \\
\text { Satisfaction }\end{array}$ & $\begin{array}{l}\text { Perc } \\
\text { Will }\end{array}$ & $\begin{array}{l}\text { eive That } \\
\text { Decrease }\end{array}$ & $\begin{array}{l}\text { Job } \\
\text { Job }\end{array}$ \\
\hline $\begin{array}{l}5 \& 7 \\
\text { (Top management } \\
\text { \& Management) }\end{array}$ & $\begin{array}{l}\text { Experience and knowledge } \\
\text { gained, personal growth, acquisition of } \\
\text { skills, a broader view, variety and a } \\
\text { broader scope, and the sharing of } \\
\text { knowledge and experience }\end{array}$ & 35 & 14 & & & \\
\hline $\begin{array}{l}8 \\
\text { (Supervisors) }\end{array}$ & $\begin{array}{l}\text { Challenge, reduce boredom, } \\
\text { improve other processes and new ideas }\end{array}$ & 16 & & 4 & & \\
\hline $\begin{array}{l}10 \\
\text { (Administrators) }\end{array}$ & $\begin{array}{l}\text { Challenge, reduce boredom, } \\
\text { improve other processes }\end{array}$ & 36 & 10 & & & \\
\hline All post levels & $\begin{array}{l}\text { Experience and knowledge gained, } \\
\text { personal growth, } \\
\text { acquisition of skills, a broader view, } \\
\text { variety and a broader scope, and the } \\
\text { sharing of knowledge and experience }\end{array}$ & 64 & 27 & & & \\
\hline
\end{tabular}

The majority of the responses received from the participants indicated that a job rotation strategy could have a positive influence on perceived job satisfaction. Responses from participants in post levels 5 and 7 indicated that experience and knowledge gained, personal growth, the acquisition of skills, a broader view, variety and a broader scope, and the sharing of knowledge and experience would increase job satisfaction when a job rotation strategy is applied. Responses from participants in post levels 8 and 10 indicated that the implementation of job rotation could be a challenge, reduce boredom, improve other processes, and bring in new ideas, and would therefore increase job satisfaction. The most important influences that job rotation could thus have on perceived job satisfaction are:

- The experience and knowledge gained, personal growth, acquisition of skills, a broader view, variety and a broader scope and the sharing of knowledge and experience.

- Providing a challenge, reduce boredom, improve other processes and stimulate new ideas.

The following responses from participants were received that indicate that job rotation could increase job satisfaction:

Category C1 - Participant 1(5)

"Job rotation is a good approach to guarantee job satisfaction, provided it is not forced on employees."

Category C2 - Participant 8(16)

"I think it can have a very positive influence. Some staff are appointed in some positions too long which creates a feeling of boredom and unworthy." 
Category C3 - Participant 10(30)

"Job rotation will have a huge impact on employee satisfaction because it comes with challenges and it forces the brain to think out of the box. It creates excitement; the employee will be empowered to execute different tasks. The employee will not get stuck in a rut (bored), reason being that in a year's time they will be moving onto another department, meeting new people, new environment, different challenges etc. New ideas will be implemented; old ideas innovated, working under different managers."

Mullins (1996:521) suggests that it is primarily in the realm of job design that opportunities for the constructive improvement of worker satisfaction appear to be high. Trivellas and Dargenidou (2009:395) note that job satisfaction stems from human relations and job enrichment. The working environment and job outcomes are positively associated with administration quality. Employees are more productive when they are satisfied with their jobs and when the environment they work in contributes to enhanced institutional quality. Employees are part of the service they deliver, thus, their satisfaction fosters service quality. Dhanraj and Parumasur (2014a:683) argue that job rotation is the planned replacement of employees among various jobs within a set period of time to enhance skill and job independence, and it will then result in increased motivation, job performance and productivity. Job rotation means working in different posts or situations at specific time periods, which are categorised on a range of the individual knowledge, skills and capability of employees. From the research conducted it was evident that job satisfaction would increase when a job rotation strategy is implemented.

\subsection{Key Factors that would Influence the Adoption of a Job Rotation Strategy by the Registrar's Environment}

The findings are summarised in Table 5

Table 5. Key factors that would influence the adoption of a job rotation strategy

\begin{tabular}{ll}
\hline Post Level & $\begin{array}{l}\text { Most Important Key Factor That Will Influence } \\
\text { The Adoption Of A Job Rotation Strategy }\end{array}$ \\
\hline 5 \& 7 (Top & $\begin{array}{l}\text { Number Of } \\
\text { Responses }\end{array}$ \\
management and management) & $\begin{array}{l}\text { Coquirements, } \\
\text { post levels and selection } \\
\text { Campus location }\end{array}$ \\
8 & \\
(Supervisors) & Strategy, policies, processes and the organisational structure \\
10 & \\
(Administrators) & Conditions of employment, job descriptions, job \\
All post levels & requirements, \\
& post levels and selection \\
\hline
\end{tabular}

Responses from the participants in post levels 5 and 7 indicated that the conditions of employment, job descriptions, job requirements, post levels and selection were key factors to be considered before the adoption of a job rotation strategy. Responses from participants in post level 8 indicated that rotation to different locations (campuses) was a key factor to consider. An employee could currently be situated on the So shanguve Campus and reside next to the campus, but the implementation of a job rotation programme could mean that he/she had to move to the Pretoria Campus. Responses from participants in post level 10 indicated that the University of Technology's strategy, policies, processes and the organisational structure should be in place and the implementation of job rotation should be well planned.

The most important key factors that would have an influence on the adoption of a job rotation strategy are thus:

- Conditions of employment, job descriptions, job requirements, post levels and selection.

- Campus location.

- $\quad$ Strategy, policies, processes and the organisational structure.

The following responses from participants were received that indicate that certain key factors should be considered before a job rotation programme can be implemented:

Category C1 - Participant 2(5)1

"The commitment of management must be secured during the planning to avoid introducing a practice that 
will at the end not have their blessing."

Category C1 - Participant 2(5)2

"Strategy alignment: it is imperative that all initiatives within the environment must contribute to enhancement of the strategic imperatives of the university."

Category C2 - Participant 8(3)

"To rotate can also be good [to increase job satisfaction] you can in the end be the one doing and knowing (knowledge) all the type of work - and then apply for any position in the company."

Category C3 - Participant 10(17)

"Policies, processes and procedures must be set in place before implementation and commencement."

A job rotation programme should include the following, according to Fiester, Collis and Cossack (2008:33):

- Clear policy formulation whether employees will be restricted to certain jobs or opportunities.

- Determining if the programme will be mandatory or if employees will be allowed to "opt out".

- Involvement of employees and managers to confirm a clear understanding of mutual expectations.

- Determining what specific skills will be enhanced.

- The use of job rotation for employees in non-exempt jobs as well as those in managerial and professional jobs.

"The administration of job rotation initiates must be worked out, including the roles of employees, managers and staff-planning personnel" (Cheraskin \& Campion, 1996:35). Grensing-Pophal (2005:53) indicates that senior management and senior human resources staff should be involved in the planning process and that it should form part of the company's strategy. This study confirms that certain key factors need to be considered before a job rotation strategy can be adopted by the Registrar's environment.

\section{Conclusion}

The study sought to explore factors that influence of the implementation of job rotation on perceived job satisfaction. The study was qualitative and explorative in nature. The results indicated that the conditions of employment, job descriptions, job requirements, post levels and selection were key factors to be considered before the adoption of a job rotation strategy. The study recommends that job rotation implementation should be aligned with the University of Technology' strategic plan and policies. All related policies and procedures should be in place, especially human resources related policies, before the implementation of job rotation.

\section{Limitation of the Study}

One limitation of the study was that, since the focus groups were conducted on the Pretoria Campus, most staff members from other campuses did not accept the invitation to take part in this study. This led to the demographic profile of the participants being predominantly from the Pretoria Campus. Another limitation was that the actual sample size was small (22), even though it fell within the prescribed guidelines. A bigger sample could have produced more representative results. Participants were also not knowledgeable on the subject of job rotation and common ground had to be created through a presentation on job rotation.

\section{Recommendations and Policy Implications}

Based on the findings of the study, the following recommendations are made:

- Management should consider the implementation of a job rotation programme in the Registrar's environment, since it could make a contribution towards perceived job satisfaction, as proved by this study.

- Management should be committed during the planning phase of a job rotation implementation process.

- Management should have the necessary knowledge and buy into the need and importance of job rotation.

- Support, sponsorship and role classification should be clarified.

- A road show should take place to educate staff members in the Registrar's environment about job rotation, its objectives, meaning, implications, advantages and disadvantages.

- Job rotation should not be forced on employees and all staff members should be involved in the implementation plan.

The job rotation implementation should be aligned with the University of Technology's strategic plan and 
policies. All related policies and procedures should be in place, especially human resources related policies, before the actual implementation of job rotation. To enhance job satisfaction, all staff members should be involved in the job rotation implementation plan. Lastly, it is important to note that a job rotation strategy cannot be implemented in a vacuum. It needs to be aligned with the business strategy of an organisation and its purpose should be to assist the organisation in reaching its strategic goals.

\section{References}

Adams, S. (2011). Boring jobs lead to burn-out. The Telegraph. Retrieved from http://www.telegraph.co.uk/health/8599684/Boring-jobs-lead-to-burn-out.html

Barry, M. L., Steyn, H., \& Brent, A. (2009). The use of the focus group technique in management research: the example of renewable energy technology selection in Africa. Journal of Contemporary Management, 6 , $229-240$

Brunold, J., \& Durst, S. (2012). Intellectual capital risks and job rotation. Journal of Intellectual Capital, 13(2), 178-195. https://doi.org/10.1108/14691931211225021

Casad, S. (2012). Implications of job rotation literature for performance improvement practitioners. Performance Improvement Quarterly, 25(2), 27-41. https://doi.org/10.1002/piq.21118

Cheraskin, L., \& Campion, M. A. (1996). Study clarifies job rotation benefits. Personnel Journal, 75(11), 31-36.

Choo, S., \& Bowely, C. (2007). Using training and development to affect job satisfaction within franchising. Journal of Small Business and Enterprise Development, 14(2), 339-352. https://doi.org/10.1108/14626000710746745

Creswell, J. W. (2013). Qualitative inquiry \& research design. London: SAGE Publications, Inc.

Creswell, J. W. (2014). Research design. London: SAGE Publications, Inc.

Dhanraj, D., \& Parumasur, S. B. (2014a). Employee perceptions of job characteristics and challenges of job rotation. Corporate Ownership \& Control, 12(1), 733-741. https://doi.org/10.22495/cocv12i1c8p6

Dhanraj, D., \& Parumasur, S. B. (2014b). Perceptions of the impact of job rotation on employees, productivity, the organization and on job security. Corporate Ownership \& Control, 11(4), 682-692. https://doi.org/10.22495/cocv11i4c7p10

Droussiotis, A., \& Austin, J. (2007). Job satisfaction of managers in Cyprus. EuroMed Journal of Business, 2(2), 208-222. https://doi.org/10.1108/14502190710826068

Fairbrother, K., \& Warn, J. (2002). Workplace dimensions, stress and job satisfaction. Journal of Managerial Psychology, 18(1), 8-21. https://doi.org/10.1108/02683940310459565

Fiester, M., Collis, A., \& Cossack, N. (2008). Job rotation, total rewards, measuring value. HR Magazine, 53(8), $33-34$.

Fried, Y., \& Ferris, G. R. (1987). The validity of the job characteristics model: a review research. Journal of Operations Management, 20, 530-562.

Friedrich, A., Kabst, R., Weber, W., \& Rodehuth, M. (1998). Functional flexibility: merely reacting or acting strategically? Employee Relations, 20(5), 504-523. https://doi.org/10.1108/01425459810238800

Game, A. M. (2007). Workplace boredom coping: health, safety, and HR implications. Personnel Review, 36(5), 701-721. https://doi.org/10.1108/00483480710774007

Garg, P., \& Rastogi, R. (2006). New model of job design: motivating employees; performance. Journal of Management Development, 25(6), 572-587. https://doi.org/10.1108/02621710610670137

Gibson, J. L., Ivancevich, J. M., \& Donnelly, J. H. (2000). Organisations' behavior structure processes. United States of America: McGraw-Hill.

Gibson, J. L., Ivancevich, J. M., Donnelly, J. H., \& Kanopaske, R. (2012). Behaviour, Structure, Processes. United States of America: McGraw-Hill.

Grensing-Pophal, L. (2005). Job rotation. Credit Union Management, 50-53.

Grossman, R. J. (2003). Putting HR in rotation. HR Magazine, 50-57.

Guinot, J., Chiva, R., \& Roca-Puig, V. ( 2014). Interpersonal trust, stress and satisfaction at work: an empirical study. Personnel Review, 43(1), 96-115. https://doi.org/10.1108/PR-02-2012-0043 
Hsieh, A., \& Chao, H. ( 2004). A reassessment of the relationship between job specialisation, job rotation and job burnout: example of Taiwan's high-technology industry. The International Journal of Human Resource Management, 15(9), 1108- 1123. https://doi.org/10.1080/09585190410001677331

Hsieh, H. F., \& Shannon, S. E. (2005). Three approaches to qualitative content analysis. Qualitative Health Research, 15(9), 1277-1288. https://doi.org/10.1177/1049732305276687

Huang, H. J. (1999). Job rotation from the employees' point of view. Research and Practice in Human Resource Management, 7(1), 75-85.

Jaturanonda, C., Nanthavanji, S., \& Chongphaisal, P. (2006). A survey study on weights of decision criteria for job rotation in Thailand: Comparison between public and private sectors. The International Journal of Human Resource Management, 17(10), 1834-1851. https://doi.org/10.1080/09585190600965324

Jayasekara, R. S. (2012). Focus groups in nursing research: methodological perspectives. Nursing Outlook, 60, 411-416. https://doi.org/10.1016/j.outlook.2012.02.001

Khan, F., Rasli, A. M. D., Yusoff, R. M. D., Tariq., A. U. R., \& Khan, M. M. (2014). Job rotation, job performance, organizational commitment: an empirical study on bank employees. Journal of Management Info, 3(1), 33-46. https://doi.org/10.31580/jmi.v3i1.8

Lund, S. B. (2003). Organisational culture and job satisfaction. Journal of Business and Industrial Marketing, 18(3), 219-236. https://doi.org/10.1108/0885862031047313

Maddock, G. M., \& Vitn, R. L. (2009). Get ideas flowing with a job swop. Retrieved from http://web.ebschohost.com

Mohan, K., \& Gomathi, S. (2015). The effects of job rotation practices on employee development: an empirical study on nurses in the hospitals of Vellore district. Mediterranean Journal of Social Sciences, 6(1), 209-215. https://doi.org/10.5901/mjss.2015.v6n1p209

Origo, F., \& Pagani, L. ( 2008). Workplace flexibility and job satisfaction: some evidence from Europe. International Journal of Manpower, 29(6), 539-566. https://doi.org/10.1108/01437720810904211

Patton, M. Q. (2002). Qualitative research and evaluation methods. Thousand Oaks, CA: Sage.

Robbins, S. P., \& Judge, T. A. (2009). Organizational behaviour. New Jersey: Pearson Education, Inc.

Saunders, M., Lewis, P., \& Thornhill, A. (2012). Research methods for business students. Management and organisational behaviour. Essex: Pitman Publishing.

Slikaniemi, L. (2009). Competence and employment forum: linking HRD and HRM. Journal of European Industrial Training, 33(5), 401-418. https://doi.org/10.1108/03090590910966562

Spector, P. E. (1997). Job satisfaction: assessment, causes, and consequences. Thousand Oaks: CA: Sage.

Swarts, I. (2008). Organisational practices enhancing positive job attitudes of expatriates on international assignment. PhD Organisational Behaviour thesis, University of Pretoria.

Teh, P., \& Sun, H. (2012). Knowledge sharing, job attitudes and organisational citizenship behaviour. Industrial Management and Data Systems, 112(1), 64-82. https://doi.org/10.1108/02635571211193644

Tietjen, M. A., \& Myers, R. M. (1998). Motivation and job satisfaction. Management Decision, 36(4), $226-231$. https://doi.org/10.1108/00251749810211027

Tomazevic, N., Seljak, J., \& Aristovnik, A. (2014). Factors influencing employee satisfaction in the police service: the case of Slovenia. Personnel Review, 43(2), 209-227. https://doi.org/10.1108/PR-10-2012-0176

Trivellas, P., \& Dargenidou, D. (2009). Organisational culture, job satisfaction and higher education service quality. The TQM Journal, 21(4), 382-399. https://doi.org/10.1108/17542730910965083

Walker, W., Davis, J., \& Desal, D. (2008). Postural assessments \& job rotation. Professional Safety, 32-36.

Werner, A. (2007). Organisational behaviour. A contemporary South African perspective (2nd ed.). Pretoria: Van Schaik Publishers.

White, M. D., \& Marsh, E. E. (2006). Content Analysis: A flexible methodology. Library trends, 55(1), 22-45. https://doi.org/10.1353/lib.2006.0053

Wright, T. A. (2006). The emergence of job satisfaction in organisational behaviour. Journal of Management iHstory, 12(3), 262-277. 
Zeffane. R. (1994). Computer usage and job satisfaction. Information Management \& Computer Security, 2(2), 10-22. https://doi.org/10.1108/09685229410059541

\section{Copyrights}

Copyright for this article is retained by the author(s), with first publication rights granted to the journal.

This is an open-access article distributed under the terms and conditions of the Creative Commons Attribution license (http://creativecommons.org/licenses/by/4.0/). 